\title{
Economic Valuation As a Basis for Sustainable Mangrove Resource Management A Case in East Sinjai, South Sulawesi
}

\author{
Sri Suharti $i^{*}$, Dudung Darusman², Bramasto Nugroho ${ }^{2}$, Leti Sundawati ${ }^{2}$
}

\begin{abstract}
${ }^{1}$ Graduate School of Bogor Agricultural University, Dramaga main Road, Campus IPB Dramaga, Bogor, Indonesia 16680
${ }^{2}$ Department of Forest Management, Faculty of Forestry, Bogor Agricultural University, Academic Ring Road, Campus IPB Dramaga, Po Box 168, Bogor, Indonesia 16680
\end{abstract}

Received November 30, 2015/Accepted March 11, 2016

\begin{abstract}
Diversity of mangrove function generates both tangible and intangible benefits and services causing its overall value is not easily recognized hence often overlooked in coastal areas development. The study used the total economic value as a framework for estimating the values of the different uses of mangroves in East Sinjai Sub District, South Sulawesi. Survey method was carried out from September 2014-February 2015. The results showed that total value of mangrove ecosystems in East Sinjai with total area of 758 ha is IDR37,535,809,496 year ${ }^{-1}$. Those values were derived from direct benefits (polyculture fish pond, catching aquatic biota such as fish, shrimp, crab and milkfish, collecting fuelwood and bats catching) and from indirect benefits i.e. its function to evade abrasion and sea water intrusion, its function as carbon sink and sequestration, its biodiversity values and its existence benefits. The problem that should be anticipated is potential expansion of polyculture fishpond which drives clearing intact mangrove forests as it contributes quick and direct income to local people. The research results are expected could be used as a consideration for local government in formulating recommendations for sustainable mangrove management in East Sinjai.
\end{abstract}

Keywords: Mangrove ecosystem, valuation, management, ecological, social economic

*Correspondence author, email: suharti23@yahoo.co.id ph.: +62-8129922297; fax.: +62+251-8638111

\section{Introduction}

The need of area development has induced utilization of forest ecosystem including mangove forest to increase regional economy and community's social economy (Din et al. 2008; Sena 2009; Ramdani et al. 2015). Unfortunately, in many cases, forest ecosystems often are defeated in the decision making on investment and economic development as forests including mangrove provide a range of marketed also non marketed goods and services both on and off-site (Spaninks \& Beukering 1997; Picaulima et al. 2011; Malik et al. 2015). There is different point of view between policy makers and investors who concern more about investment and economic development on the one hand and environmentalists on the other hand, who see the forest ecosystem from the perspective of ecology and environment (Giri et al. 2008; Soedomo 2013; Kildow \& Guo 2014). Therefore, in designing forest ecosystem management, it requires a thorough consideration, assessment, and analysis hence it would not adversely affect its surrounding area (Karminarsih 2007). Thus, a balance between social economic and ecological needs should be taken into account in the planning of mangrove forest management.

The economic valuation of mangrove resource aims to provide economic value of resources used based on the real value from the society's view point. Economic valuation offer a more comprehensive assessment of the various goods and services produced by the ecosystem so as to contribute more in-depth information for decision making in sustainable mangrove management (Napitupulu et al. 2012; Kildow \& Guo 2014; Malik 2015).

In conducting economic valuation, one need to know how far is disparity between the market price and the real value that should be alloted to the resources used. Economics as a tool in conducting economic valuation is the science about making choice. Conventionally, economics is defined as the study on how people allocate scarce resources. The economic valuation of natural resources can be defined as the study about allocation of natural resources like water, land, fish and forest (Fauzi 2004). Benefits which could be provided by natural resources to meet human needs are a lot, however, limitations in science and technology as well as rigid institutional arrangement has impeded types and amount of its utilization so that benefits obtained are still very low (Darusman 2012). Making choices of several alternatives on environment management are more complex, compared to selection of options in the context of purely private goods (Harahap 2010). 
In the context of deciding alternative for mangrove forest land use based on benefit-cost rule, its decision can be justified if net benefit of ecosystem development is greater than net benefits obtained from conservation. In this case conservation benefits are measured based on total economic value of mangrove forest (Pearce \& Moran 1994). Mangrove forest in East Sinjai Sub District has very important and significant value for local community (social, economic and ecology). However the existence of mangrove forests often became a matter of debate by various parties whether it would be better if maintained as current condition, as commercial tourist area, or for other uses. The most optimal option of management is not yet known as there is lack of comprehensive data and information on the values (benefits and functions) of mangrove area in the region. Therefore, an assessment of the total economic value of the mangrove area in the Sub District of East Sinjai is needed as input for stakeholders in creating a more optimal mangrove management in the future.

Research on the economic valuation of mangrove resource use in East Sinjai, South Sulawesi aims to estimate total value of mangrove resources potential benefits. Lack of knowledge on the potential value of intact mangrove resources both tangible and intangible benefits may result in errors in formulating mangrove resource management policies that could instigate in damage and even destruction of mangrove ecosystem. Eventually, research results are expected could be used as the basis for formulating recommendations for more optimal use of mangrove ecosystem.

\section{Methods}

Location and time The research location is mangrove forest area in East Sinjai Sub District, Sinjai Regency, South Sulawesi Province which is administratively located in 5 villages namely Samataring, Tongke-Tongke, Panaikkang, Passimarannu, and Sanjai. Field data collection was conducted from September 2014 until February 2015.

Data collection The research was conducted by using survey aiming to collect data from a number of variables in a group of people through interviews, field observation, and literature review. Fourty eight people were selected from different occupation i.e. fisherman, farmers, pond's worker, fuelwood collector, bat catcher, fry, fingerling, hatchling collector, trader, and community leaders and interviewed to obtain information about variety of mangrove resource use in the research location. Total number of household in the research site is 3,371. Total number of farmer's groups in the research site is 41 groups consisting of fishermen (17 groups), farmers (17 groups), and fish product processing group (7 groups). In East Sinjai, one family head could become member of more than one group. With the average group members is about 30 people, the number of members of the group as a whole is 1,230 household $(\mathrm{HH})$. Selection of sample villages were done purposively based on mangrove forest area existing in the villages. While respondents selected are members of farmer groups $(5 \%$ from each occupation) and from the people who directly or indirectly got its benefits. Some questions asked to respondents including what kind of products and services they attained, how many/how much they worth, how frequent they got them, how they consider the importance of them and how they value existing mangrove forest. Secondary data were obtained from literatures, reports and other documents related to the study.

Identify types of mangrove forest use in East Sinjai Mangrove forest benefits were analyzed descriptively including type, location and scale, system and model of utilization. Analysis of total economic value of mangrove forests was conducted by using formula from Munasinghe (1993) as follows:

$\mathrm{TEV}=(\mathrm{DUV}+\mathrm{IUV}+\mathrm{OV})+(\mathrm{XV})$

Note:

$\mathrm{TEV}=$ Total economic value

DUV = Direct use value

IUV = Indirect use value

$\mathrm{OV}=$ Option value

$\mathrm{XV}=$ Existence value

Direct use value (DUV) The immediate benefits are benefits derived from land use associated with mangrove forests based on market prices including timber and fuelwood, benefits from its biological condition and from fishpond cultivation.

Indirect use value (IUV) Indirect use value is the sum of indirect benefits gained from mangrove forest including coastal protection against wave and wind erosion (abrasion); prevention from sea water intrusion; shelter and habitat for diverse wildlife, particularly avifauna; nutrient sink-effect and reduction in excessive amonts of pollutants (FAO 1995); and its significant role as carbon sink and sequestration (Alongi 2012; Patil et al. 2012). In this study, indirect benefits are limited to its function as prevention from abrasion and seawater intrusion and its benefit as carbon sink and sequestration. Estimation of mangrove benefit as coastal erosion barrier is approached by means of the cost for constructing break water if there is no mangrove ecosystem. While estimation of its function as seawater intrusion prevention was approached from water consumption costs to be incurred based on standard water needs of average household issued by Sinjai Regional Water Enterprise.

Calculation of mangrove function as carbon sink and sequestration were estimated fom previous several studies on carbon biomass of mangrove forests (below and above ground). Many studies revealed that mangroves are among the most carbon-rich ecosystems in the tropics. Mangrove account for $3 \%$ of carbon sequestration by the world's tropical forests, but $14 \%$ of carbon sequestered in the world's ocean, although accounting for only $0.5 \%$ of total coastal ocean area. If disturbed, mangrove may emit $0.02-0.12 \mathrm{PgC}$ year $^{-1}$, equal to $2-10 \%$ of global deforestation emissions (Chumura et al. 2003; Cai 2011; Alongi 2012).

Option value (OV) Option value benefit is benefit to preserve the use of goods, services and environmental resources in the future that cannot be used at present. In this study, the value which will be used is benefit of preservation for mangrove forest biodiversity. Alleged value to be used in this analysis was obtained from research result in other location (benefit transfer). Option value benefit was 
approached by referring to the value of biological diversity of mangrove ecosystems of USD1,500 km $\mathrm{year}^{-1}$ or USD15 ha year $^{-1}$ (Ruitenbeek 1992; Indrayanti et al. 2015). This method is still being debated in economic valuation, however since its measurements are complicated and difficult and its value tends to have a small portion, the benefit transfer method is often used with the assumption that the condition of mangrove forest are relatively similar.

Exsistence value (XV) Existence value is benefits perceived by the public from the presence of mangrove ecosystems after other benefits (direct benefits, indirect benefits, and option value) are removed from the analysis. It is benefits to be enjoyed by humans from the existence of mangrove forest. Respondents were asked to give a value on forest resources with a hope that presence of forest resources could be maintained continuously. Data was collected by using contingen valuation method (CVM), where respondents were asked about their willingness to pay the amount of goods and services from mangrove ecosystems by expressing values for non-market environmental goods and services. This benefit is the economic value of existence (physical) mangrove ecosystems (Harahap 2010).

\section{Results and Discussion}

Mangrove forest in East Sinjai Mangrove forest in East Sinjai is the largest compared to other sub districts in Sinjai Regency. Most of the mangrove forest is the result of community plantation with a total of 758 ha (Dinas Perkebunan dan Kehutanan Kabupaten Sinjai 2013). Administratively, the area of mangrove forest lies from the northwest to the southeast along the east coast of Sinjai and goes into five villages, namely Samataring, Tongke-Tongke, Panaikkang, Passimarannu, and Sanjai.

Mangrove in Souh Sulawesi was dominated by Rhyzopora spp, Avicennia spp, Sonneratia spp, and Bruguera spp. Among all existing species, Rhyzopora sp is the most dominant (Malik 2015). Identification of mangrove species in Sinjai found that there are 15 mangrove species grow there which is dominated by Rhizophora spp. (Table 1). Avicennia spp and Sonneratia spp are less favored by local people because their cultivation are more difficult. Besides that, wood texture of Avicennia spp is hard and its trunk has lots of branches.

Result of vegetation analysis done in East Sinjai (Table 2) shows that mangrove vegetation is dominated by Rhizophora spp followed by Avicennia spp, Sonneratia caseolaris, and Bruguiera gymnorrhiza. Mangrove density tends to decrease with increasing stages of growth. From 103,611 ind $\mathrm{ha}^{-1}$ for seedlings, became 6,133 ind ha ${ }^{-1}$ for saplings, and 794 ind $\mathrm{ha}^{-1}$ for tree stage. Accessing to important value index (IVI), Rhizophora spp dominates at all stages of growth, while codominant species is Avicennia spp, followed by several other species (Table 2).

Identification of mangrove forest benefits in East Sinjai Understanding the value, particularly those involving goods and services produced by a natural resources and the environment, can be different, depending on the view angle of science used. The difference on the concept of value can be difficult to understand the importance of an ecosystem. Therefore it is necessary to have similar perception of the ecosystem assessment (Harahap 2010). Various benefits of mangrove ecosystems identified in East Sinjai consisted from direct, indirect, option value, and existence value benefits.

Total economic value (TEV) of mangrove forest in East Sinjai District. Direct use value The direct benefits of mangrove forests comes from polyculture fishpond cultivation, catching aquatic biota (fish, crab, shrimp), collecting fuelwood, collecting small milkfish and shrimp and catching bats (Napitupulu et al. 2012).

Direct benefits from polyculture fishpond cultivation (milkfish and shrimp) Cultivation of fish and shrimp is done by traditional and semi-intensive systems. However, due to limited capital, traditional pond system is more common. Traditional system is developed by farmers who rely on the knowledge obtained from their predecessors. This system mostly rely on water circulation system from up and

Table 1 Mangrove species grow in in Sinjai

\begin{tabular}{lll}
\hline \multicolumn{1}{c}{ Mangrove Spesies } & Local name & Family \\
\hline Aegiceras corniculatum & Otti-otti & Myrsinaceae \\
Avicennia alba & Api-api & Avicenniaceae \\
Avicennia marina & Api-api & Avicenniaceae \\
Avicennia officinalis & Api-api & Avicenniaceae \\
Bruguiera cylindrica & Bakko Panda & Rhizophoraceae \\
Bruguiera gymnorrhiza & Bakko Panda & Rhizophoraceae \\
Ceriop sp & Cokke & Rhizophoraceae \\
Nypa fructicans & Nipa & Palmae \\
Rh izophora mucronata & Bakko/Bakau & Rhizophoraceae \\
Rh izophora apiculata & Bakko/Bakau & Rhizophoraceae \\
Sonneratia alba & Padada & Sonneratiaceae \\
Sonneratia caseolaris & Padada & Sonneratiaceae \\
Hibiscus tiliaceus & Haru & Malvaceae \\
Pandanus tectorius & Pandan & Pandanaceae \\
Terminalia catappa & Ketapang & Comretaceae \\
\hline
\end{tabular}

Source: Dinas Perkebunan dan Kehutanan 2013 
Table 2 Result of vegetation analysis in East Sinjai mangrove forest

\begin{tabular}{|c|c|c|c|c|c|c|c|}
\hline Species & $* \mathrm{D}\left(\right.$ ind $\left.\mathrm{ha}^{-1}\right)$ & $\mathrm{RD} \%$ & $\mathrm{~F}$ & $\mathrm{RF} \%$ & $\mathrm{D}\left(\mathrm{m}^{2} \mathrm{ha}^{-1}\right)$ & DR \% & IVI $\%$ \\
\hline \multicolumn{8}{|l|}{ A. Seedling } \\
\hline Rhizophora spp & 88,889 & 85.79 & 0.89 & 49.94 & - & - & 135.73 \\
\hline Avicennia spp & 9,722 & 9.38 & 0.22 & 12.48 & - & - & 21.87 \\
\hline Sonneratia caseolaris & - & - & - & - & - & - & - \\
\hline Bruguiera gymnorrhiza & - & - & - & - & - & - & - \\
\hline Acanthus ilicifolius & 2,222 & 2.14 & 0.22 & 12.48 & - & - & 14.63 \\
\hline Ipomoea pes-caprae & 1,667 & 1.61 & 0.22 & 12.48 & - & - & 14.09 \\
\hline Scaevola taccada & 278 & 0.27 & 0.11 & 6.24 & - & - & 6.51 \\
\hline Spinifex littoreus & 833 & 0.80 & 0.11 & 6.24 & - & - & 7.05 \\
\hline Total & 103,611 & & 1.78 & & & & 200.00 \\
\hline \multicolumn{8}{|l|}{ B. Sapling } \\
\hline Rhizophora spp. & 4,844 & 78.98 & 0.89 & 61.81 & - & - & 140.79 \\
\hline Avicennia spp. & 1,067 & 17.40 & 0.33 & 22.92 & - & - & 40.31 \\
\hline Sonneratia caseolaris & 222 & 3.62 & 0.22 & 15.28 & - & - & 18.90 \\
\hline Bruguiera gymnorrhiza & - & - & - & - & - & - & - \\
\hline Total & 6,133 & & 1.44 & & & & 200.00 \\
\hline \multicolumn{8}{|l|}{ C. Tree } \\
\hline Rhizophora spp. & 750 & 94.46 & 0.78 & 50.32 & 8.46 & 92.92 & 237.70 \\
\hline Avicennia spp. & 8 & 1.01 & 0.33 & 21.29 & 0.17 & 1.89 & 24.19 \\
\hline Sonneratia caseolaris & 25 & 3.15 & 0.22 & 14.19 & 0.38 & 4.18 & 21.52 \\
\hline Bruguiera gymnorrhiza & 11 & 1.39 & 0.22 & 14.19 & 0.09 & 1.01 & 16.59 \\
\hline Total & 794 & & 1.55 & & 9.11 & 100 & 300.00 \\
\hline
\end{tabular}

down tidal to obtain a continuous water supply. While semiintensive pond cultivation is a system requiring significant costs for feed, fuel and fishpond worker incentives (Dinas Kelautan dan Perikanan Kabupaten Sinjai 2014). The total area of polyculture fishpond of milkfish and shrimp (semiintensive and traditional) in East Sinjai is 25.6 ha. Cultivation of milkfish and shrimp polyculture is relatively small compared to polyculture of milkfish and seaweed cultivation due to several factors i.e limited capital and higher risk from fungal diseases attack. The total value of the benefits derived from milkfish and shrimp cultivation in East Sinjai is IDR215,739,622 year $^{-1}$ (Appendix 1).

Direct Benefits from polyculture fishpond cultivation (milkfish and seaweed) Milkfish and seaweed polyculture cultivation is widely developed in East Sinjai. Total area of milkfish and seaweed polyculture is 251.6 ha, much wider than milkfish and shrimp polyculture. This system is more preferred by people as its cultivation is relatively easy and seaweed cultivation generate greater and more frequent revenue (harvesting every 40 days). Seaweed species commonly cultivated is Gracilaria sp. Total value of milkfish and seaweed polyculture cultivation is IDR9,884,285,894 year $^{-1}$ (Appendix 1).

Direct benefits from mangrove aquatic biota Mangrove provides primary food for fish, shrimp, and crabs living in the coastal ecosystem through avalanche litter of mangroves (especially its leaves). A small portion of litter falling on the forest floor will be consumed by crabs and most will be decomposed by microbes that become food source for detrivora, hereinafter detrivora becomes food source for carnivores (Harahap 2010; Kusmana 2010). Another benefit gained from mangrove ecosystem is the abundance of aquatic biota that can be captured. Some aquatic biota routinely obtained by the people are fish (mullet, baronang mangrove, tude), crab, oysters and shrimp (Harahap 2010; Napitupulu 2012). Costs needed to capture aquatic biota is relatively small including costs for nets, pouch, kerosene and kerosene lamp. However, despite aquatic biota abundance, not all the people routinely took advantage of it. The reason is there are still many alternative benefits that can be derived from the existence of mangrove resources, hence people choose the most profitable (considering availability of costs, time and labour). The average benefit value from mangrove aquatic biota is IDR $12,033,000 \mathrm{HH}^{-1}$. Assuming that there are $10 \%$ of East Sinjai household utilizing the abundance of aquatic biota, benefit obtained is IDR4,055,121,000 year ${ }^{-1}$ (Table 3).

Direct benefit from collecting fry, fingerling and hatchling Collection of fry, fingerling (young milkfish) and hatchling (young shrimp) is a routine activity conducted by women, where some is used for fishpond cultivation (Yap et al. 2007) and the rest is sold to middlemen. Average prices for one fry and fingerling in East Sinjai is IDR50 while one hatchling is sold between IDR100-IDR150. Season for collecting fry and fingerling is from August to January while for hatchling is from April to August. Assuming that $10 \%$ of the population of households in each village collecting fry, fingerling and hatchling $(337 \mathrm{HH})$, the total benefits attained is IDR2,373,154,000 year ${ }^{-1}$ (Table 3).

Direct benefit from collecting fuelwood Although most people in East Sinjai already used oil and gas stoves, some still use fuelwood as additional energy. It was found that the use of fuelwood from mangrove species has several advantages, i.e more durable fire, faster heat and less smoke (Din et al. 2008; Atheull et al. 2011). Collecting fuewood is done on area close to their settlement. Assuming that there are $10 \%$ of the total household $(337 \mathrm{HH})$ who are still collecting fuelwood, and in average each $\mathrm{HH}$ use fuelwood benefit of IDR1,920,000 the value of fuelwood obtained in 
Table 3 Calculation of each component of mangrove ecosystem benefits

\begin{tabular}{|c|c|c|c|}
\hline Type of benefits & $\begin{array}{l}\text { Average benefit value } \\
\text { year-1 (IDR) }\end{array}$ & $\begin{array}{c}\text { Total area/total } \\
\text { number of } \\
\text { household in East } \\
\text { Sinjai } \\
\end{array}$ & $\begin{array}{l}\text { Benefit value of } \\
\text { mangrove in } \\
\text { East Sinjai } \\
\text { (IDR) }\end{array}$ \\
\hline $\begin{array}{l}\text { Polyculture fishpond cultivation } \\
\text { (milk fish + shrimp) }\end{array}$ & $8,427,329 \mathrm{ha}^{-1}$ & 25.6 ha & $215,739,622$ \\
\hline $\begin{array}{l}\text { Polyculture fishpond cultivation } \\
\text { (milk fish }+ \text { sea weed) }\end{array}$ & $39,285,715 \mathrm{ha}^{-1}$ & 251.6 ha & $9,884,285,894$ \\
\hline Collecting fuelwood (twice a week) & $1,920,000$ & $337 \mathrm{HH}$ & $647,040,000$ \\
\hline $\begin{array}{l}\text { Collecting mangrove aquatic } \\
\text { biota (fish, crab, oyster, shrimp) }\end{array}$ & $12,033,000$ & $337 \mathrm{HH}$ & $4,055,121,000$ \\
\hline Collecting fry and fingerling & $3,432,000$ & $337 \mathrm{HH}$ & $1,156,584,000$ \\
\hline Collecting hatchling & $3,610,000$ & $337 \mathrm{HH}$ & $1,216,570,000$ \\
\hline Bats catching & $12,600,000$ & $337 \mathrm{HH}$ & $189,000,000$ \\
\hline $\begin{array}{l}\text { Mangrove function to prevent } \\
\text { abrasion }\end{array}$ & $13,870,946$ & $\begin{array}{l}\text { Length of coastal } \\
\text { line is } 12.8 \mathrm{~km}\end{array}$ & $17,754,810,880$ \\
\hline $\begin{array}{l}\text { Mangrove function to prevent } \\
\text { sea water intrusiom }\end{array}$ & $450,000 \mathrm{HH}^{-1}$ & $3,371 \mathrm{HH}$ & $1,516,950,000$ \\
\hline $\begin{array}{l}\text { Mangrove function as carbon } \\
\text { sink and sequestration }\end{array}$ & $\begin{array}{r}39.87 \mathrm{tC} \mathrm{ha}^{-1} \text { year } \\
\text { carbon price USD1 for } 1 \\
\text { ton } \mathrm{CO}_{2}\end{array}$ & 758 ha & $407,955,600$ \\
\hline Option value & USD15 $\mathrm{ha}^{-1}$ & 758 ha & $153,495,000$ \\
\hline Existence value & $338,257,500 \mathrm{ha}^{-1}$ & 758 ha & $338,257,500$ \\
\hline Total potential value & & & $37,535,809,496$ \\
\hline
\end{tabular}

\section{East Sinjai is IDR647,040,000 year ${ }^{-1}$.}

Direct benefits obtained from catching bats Catching bats was common in Sinjai. Bats are used for traditional medicine in many developing countries (Borokini et al. 2013). In order to preserve mangrove forests and the viability of bats, while taking into account local people interests, bats catching was regulated by Sinjai local government. First regulation was issued by Regent of Sinjai's decree Number 300/LNG/SET regarding bats catching permits on January 13, 2003. At that time population of bats was too high hence it threatened existing mangrove. However, on October 20, 2003 Regent of Sinjai re-issued letter Number 522/848/SET regarding termination of bat catching in order to keep the preservation of bats. The value benefits of catching bats (15 HH) is IDR189,000,000 year ${ }^{-1}$.

\section{Indirect use value. Indirect benefit of mangrove function to prevent abrasion}

Indirect benefits of mangrove forest in East Sinjai was derived from its function to prevent abrasion or breaking waves. Coastal protection by mangrove ecosystem occurs through mechanism of breaking waves kinetic energy and reduction of tidal range to the main land (Harahap 2010; Suzana et al. 2011). The research on the north coast of Java island found that coastal erosion did not occur on area where mangrove grows with 100 Meters width and tidal range had been reduced by more than 60\% (Suryana 1998). Indirect benefit of mangrove to prevent abrasion was estimated through replacement cost for breakwater construction. The value were estimated by standar cost for building construction breakwater issued by the Research and Development Agency of Ministry of Public Works in Sinjai i.e. IDR13,870,946 $\mathrm{km}^{-2}$. This standard cost then were calculated based on the length of the coastline of East Sinjai which was protected by mangrove i.e $12.8 \mathrm{~km}$. Total benefit of mangrove forest as a buffer abrasion or breaking waves was IDR177,548,108,800 with economic life for about 10 years or IDR17,754,810,880 year $^{-1}$.

Indirect benefit of mangrove function to prevent seawater intrusion The value of mangrove forest to prevent seawater intrusion is obtained by using a replacement cost method. This approach is one method of economic valuation based on the potential expenditure (Harahap 2010). From field observation and interviews results, people now are able utilize well water for various domestic puIDRoses. This is different from the situation in the past when there has been no mangrove forests, where people had to buy water for household daily needs. The value of mangrove for seawater intrusion barrier is approached from water consumption if they have to purchase it. Average cost spent for domestic needs of customers in East Sinjai IDR450,000 month ${ }^{-1} \mathrm{HH}^{-1}$ (calculations are based on water price in Sinjai Regional Water EnteIDRrise. Therefore, the value of mangrove as seawater intrusion barrier for $3371 \mathrm{HH}$ living in East Sinjai Sub Districy is IDR1,516,950,000 year ${ }^{-1}$.

Indirect benefit of mangrove as carbon sink and sequestration Study on whole-ecosystem inventories of above and below-ground biomass and soil carbon for natural and replanted mangrove forests in several locations ranging from Peninsular Malaysia, Southern Vietnam, Southern China, Indonesia, Southern Thailand, Western Australia, and Queensland, Australia found that total carbon biomass (above ground and below ground) of mangrove forest in Indonesia for Avicennia marina, Rhizophora stylosa, and 
Sonneratia caseolaris was $437 \mathrm{tC} \mathrm{ha}^{-1} ; 703 \mathrm{tC} \mathrm{ha}^{-1}$ and $654 \mathrm{tC}$ ha $^{-1}$, respectively (Alongi 2012). Average mangrove carbon biomass of those three species (for 15 year old trees) i.e 598 tC ha ${ }^{-1}$ or $39.87 \mathrm{tC} \mathrm{ha}^{-1}$ year ${ }^{-1}$ is used to calculate mangrove benefits in this study.

In general, the price of carbon credit depends on the commitment level of Annex 1 countries for reducing green gas house (GHG) emissions and the inclusion of potential sectors particularly the energy sector. Buyers of carbon credits will buy them as long as they are cheaper than the marginal cost of abatement in their respective countries. The price fluctuates depend on several factors (stand age and condition, ecosystem types, region, situation in buyer countries, etc) (Ojha 2009). In this study, carbon price used is assumed not so optimistic i.e USD1 for 1 ton $\mathrm{CO}_{2}$ (excahnge rate USD1 = IDR13,500). Hence, total mangrove benefits as carbon sink and sequestration in East Sinjai (758 ha) would be IDR407,955,600 year ${ }^{-1}$.

Option value Option value shows individual's willingness to pay to preserve certain natural resource for future utilization (Harahap 2010; Rachmansyah \& Maryono 2010; Napitupulu 2012). Option value can be considered as an insurance where people is willing to pay to ensure future utilization of the resources. With total mangrove area of approximately 758 ha and average benefit value is USD15 ha ${ }^{-1}$ (excahnge rate USD1 = IDR13,500), the option value of mangrove forest in East Sinjai is IDR153,495,000 year ${ }^{-1}$.

Existence value Existence value of mangrove ecosystem in East Sinjai was estimated by using contingent valuation method (CVM). Through this method, respondents were asked to assess the significance of the presence of mangrove ecosystems (Harahap 2010; Wahyuni et al. 2014). Total respondents who gave ratings is 48 people with various educational backgrounds and occupation. Respondents were asked their willingness to put aside certain amount of money. From total of 48 respondents, 3 people are illiterate, 23 people have primary school education, 9 people have junior high school education, 11 people have high school education, and 2 graduate from university.

The results obtained from people's willingness to pay is IDR21,42 million ha $^{-1}$ year $^{-1}$, while the average value is IDR $446,250 \mathrm{ha}^{-1}$ year $^{-1}$. With total area of mangrove forest $758 \mathrm{ha}$, then total existence value of mangrove is IDR338,257,500 year ${ }^{-1}$. Although it is not the smallest, if compared with other benefits, proportion of existence benefit is only $0.90 \%$ of total economic benefits. This small portion of existence value to total benefits implies that people in general do not understand the indirect value of existing mangrove ecosystem. This is different from research result done by Siregar (2012) in Kubu Raya who found that existernce value of mangrove forest provides greatest contribution to total economic value $(49.1 \%)$. But if compared with result of CVM analysis done in The Philippines (combining the data sets from Palawan and Bohol) using a least-squares method (i.e., bid function approach) (Carandang et al. 2013) showed a mean willingness-to-pay amount of PHP 44/month per person $\left(\right.$ IDR13,200 month ${ }^{-1}$ or IDR158,400 year ${ }^{-1}$; PHP1 = IDR300), East Sinjai people seems put higher value on existing mangrove. This significant difference may be due to people's assessment upon the mangrove benefits more or less is influenced by how much real benefits that they could gain directly from mangrove.

From the analysis on the potential economic value calculation, the total potential economic value of mangrove forests in East Sinjai is IDR37,535,809,496 year ${ }^{-1}$. Table 4 shows that biggest benefit derived indirectly $(52.43 \%)$ is from abrasion, and seawater intrusion prevention and from mangrove function as carbon sink and sequestration (IDR19,679,716,480). This indicates that if mangrove does not exist there, the cost needed to replace its function is extremely high. This is in line with research results from Rusdianah (2004) conducted in Tongke-tongke village and Baderan (2013) in Kwandang District- Gorontalo, Siregar (2012) in Kubu Raya-West Kalimantan, Kalitouw (2015) in Kulu village, North Minahasa, and Malik et al. (2015) in Takalar, South Sulawesi where total value of indirect benefits contribute more outweigh direct benefits. This verifies that ecological benefits derived from mangrove resource is greater than direct economic benefits. However, since most of ecological benefits is not seen and experienced directly, it is often overlooked in understanding total value of natural resource. Ostrom (1990) and Uphoff (2000) argued that public tends to appreciate value of resources if its benefits can be sensed in real, immediate and close. While benefits of products and services derived from mangrove ecosystems often cannot be acquired directly, real and close with the place where people exist. Therefore, in formulating strategies for mangrove resource management, it is urged to increase awareness and understanding of local community on the value and importance of mangrove ecosystems. Understanding that economic benefits is better than ecological benefits should be resolved as a lot of evidences verified that ecological functions are greater than economic functions.

The second largest proportion of the benefit was derived from direct use which was $46.26 \%$ (IDR17,364,340,516). Direct benefits derived from polyculture fishpond cultivation of milkfish and seaweed contributed $26.91 \%$ to total direct benefit. It has become a mainstay of coastal communities economy in East Sinjai because it provided more frequent and rapid high income ( 8 times year ${ }^{-1}$ ).

The smallest contribution of benefit was derived from option value benefit, that was equal to $0.41 \%$ from total value benefit. This low portion of benefit implies that value to preserve the use of goods and services in the future that cannot be used now is low. This is consistent with results of previous studies conducted by Siregar (2012) in Kubu Raya, West Kalimantan, Rusdianah (2004) in Tongke-Tongke, Asbar (2007) in Sinjai and Hiariey (2009) in Ambon. In this research, option value was approximated by using research results in other location (benefit transfer) and refers to research result from Ruitenbeek (1992) in Bintuni Bay who assumed that mangrove resource value was USD15 $\mathrm{ha}^{-1}$. In estimating biodiversity value, Ruitenbeek based on the allocation of international projects funding for mangroves in pristine condition (Ruitenbeek 1992; Napitupulu et al. 2012). Many researchers argued that benefit transfer approach tends to assume similar condition of mangrove ecosystem in spite of its differences and variations in mangrove characteristics 


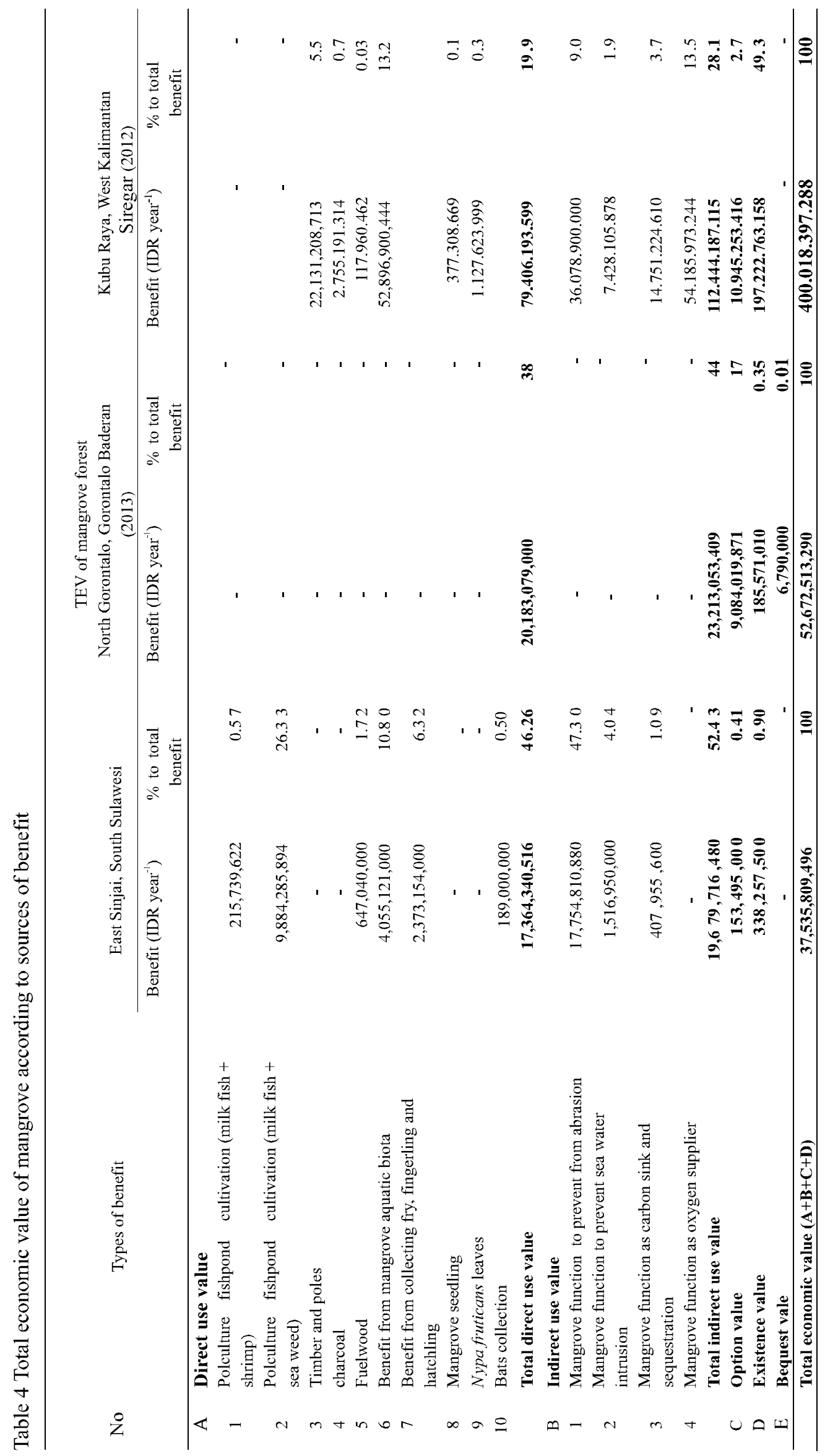




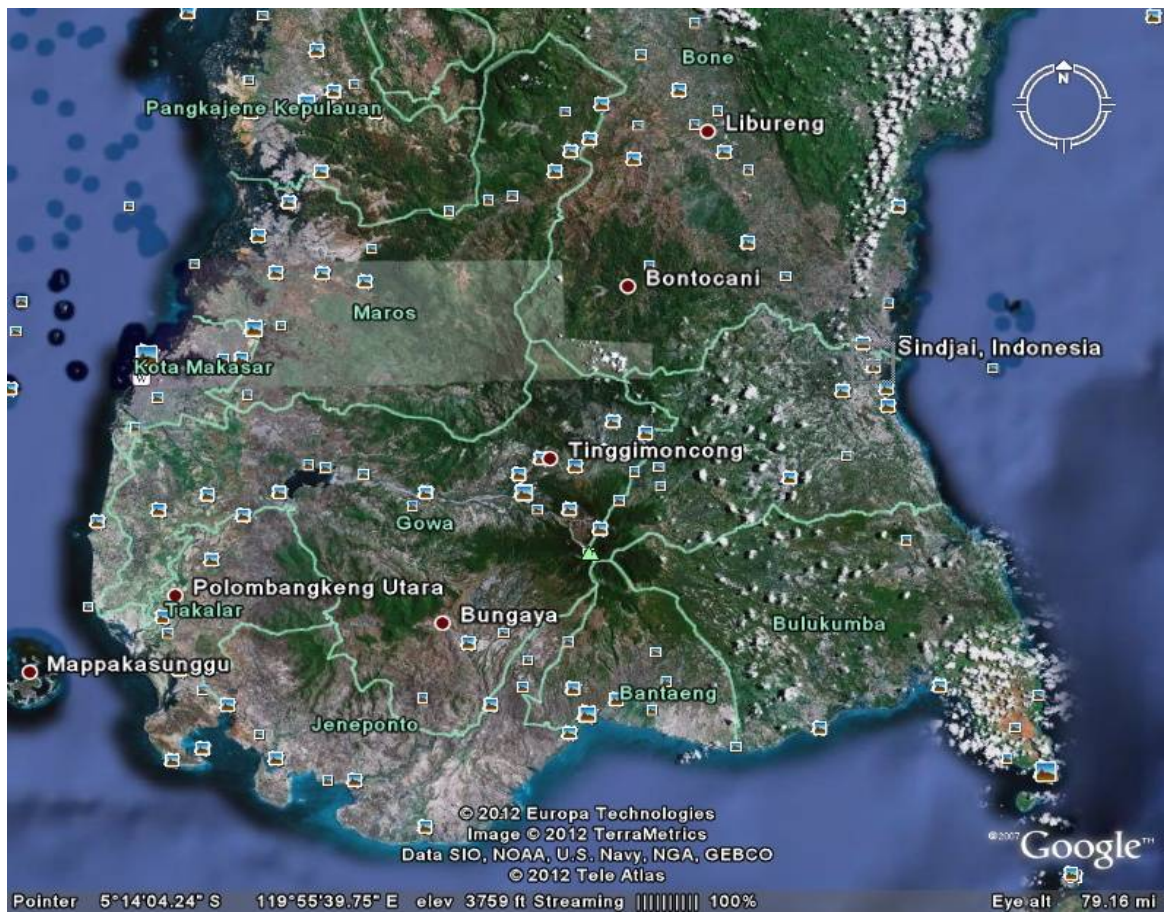

Figure 1 Research location on five villages of East Sinjai sub district coastal area.

which might provide differences in its value (Spaninks \& Beukering 1997; Siregar 2012; Soedomo 2013). In this research, the justification to use benefit transfer from Ruitenbeek is based on the good performance of mangrove forest in East Sinjai which is assumed almost similar with mangrove condition in Bintuni bay. This similarities could reduce some biases in the calculation.

Total economic value of mangrove ecosystem in East Sinjai is IDR37,535,809,496 year ${ }^{-1}$. If it is calculated in hectare (total area of mangrove forest in East Sinjai is 758 ha), the value is IDR49,519,538 $\mathrm{ha}^{-1}$ year $^{-1}$ or USD $3668 \mathrm{ha}^{-1}$ year $^{-1}$ (USD1 = IDR13,500). This number is a bit different from meta analysis on mangrove forest done in South East Asia by Brander et al. (2012) who mentioned that mean values of total value of mangrove is USD4185 $\mathrm{ha}^{-1}$ year $^{-1}$. The variations in total mangrove values might due to differences in biophisical condition of study site (Brander et al. 2012) Calculation of the total economic value of mangrove ecosystem in Eastern Sinjai indicates that the intangible benefits of mangrove forest is very large. This is consistent with the results done by Baderan (2013) in the mangrove forest area in Kwandang District, Gorontalo and the research results on total economic value of mangrove ecosystem in Wori District, North Minahasa Regency (Kalitouw 2015). Therefore, in formulating strategies of mangrove resource management, the value of intangible mangrove ecosystems benefits which is often neglected in decision making need to be one of the basic considerations so that mangrove forest management will not harm and give a negative eksternatlitas to surrounding forest communities.

Regarding future research directions, there are some points important to note. The calculation of the total economic value, the terminology of total value actually is not really total because: (1) it does not cover the entire value, unless the economic value, (2) many ecologists claim that there are some ecological functions are synergistic which its value is greater than if it functions separately (Pearce \& Moran 1994). It is also revealed by Manan (1985), who argued that forest has versatile functions, i.e as timber producer, water system regulator, shelter for wild life, food producer, and as recreation areas. It is very difficult to define the boundaries of these functions clearly due to interaction between them. The use of benefit transfer method used in this study assumed that provision of services is constant across all mangrove sites. For future rerearch, the inclusion of potentially important spatial variables, including mangrove area, abundance and road density variables in the vicinity of study site would provide better description about biophysical characteristics of mangrove in the research area (Brander et al. 2012).

Analysis of optimizing management of mangrove ecosystem Mangrove forest ecosystem in East Sinjai has significant role economically, socially, and ecologically. Therefore any purpose of mangrove resource management should accommodate its role to avoid negative externalities. Harahap (2010) stated that efforts to optimize management of resources could be achieved if there is a balance of relationship between the existing systems in the resources. Results on calculation of total value of mangrove potential benefits shows that utilization of mangrove in East Sinjai so far was done without disturbing existing mangrove ecosystems. Public awareness on the value and importance of mangrove in East Sinjai is the crucial factor for careful mangrove exploitation by people in this area (Rusdianah 2006; Samsudin 2015).

Nevertheless there are some issues that should be 
anticipated for sustainable and optimal mangrove management. First is mangrove potency which has not been developed in East Sinjai i.e. 1) its potency for ecotourism and 2) its use as natural laboratory for education and research site. There are three potential touris area to be developed i.e. Tongke-Tongke beach in Tongke-Tongke; Marana beach in Passimarannu and Ujung Kupa beach in Sanjai. Those three potential tourist areas have mangrove forest that should be preserved. In spite of its potential value which already begun to attract local tourists to visit, those area has not been professionally managed and every body can enter the area free of charge.

To preserve and maintain tourist area, professional management is needed involving relevant stakeholders such as local government, private sector and local communities (Miswadi et al. 2015). In its establishment, a specific institution is needed to manage the region and determine right and responsibility of each stakeholder. In its implementation, every visitor entering the region needs to pay entry fee which will be used for facilities maintenance and expansion of planting mangrove while simultaneously improve social and public facilities in the region.

If professionally managed, mangrove ecotourism could encourage people to participate in mangrove conservation as well. There are new alternative jobs available such as selling mangrove products and souvenir, becoming tour guide, providing restaurant, home stay and means of transportation. Kustanti (2011) mentioned that ecotourism is one of the environmental products and services generated from mangrove forest ecosystems which was potentially developed without destroying existing ecosystem. Additionally, tourism development could also indirectly increase revenue for nature conservation while providing economic benefits to surrounding community (Sawitri et al. 2013). Research done by Mayudin (2012) on ecotourism development in Labakkang, Mandalle and Segeri District estimated value of IDR 864,000,000 year ${ }^{-1}$ by offering natural beauty, mangrove forests uniqueness, bird attraction, fishing, and mangrove tour by boat rental.

Another potency that has not been explored is the use of mangroves as natural laboratory for education and training. Many researchers and students (domestic and foreigners) came to the site to conduct research. So far there is no charge at all to enter the site as long as they got permission from local government. Supposedly every activity of education or research pay certain amount of money as cost/fee which will be used to preserve existing mangrove ecosystem.

In spite of unexplored potential benefits, there are several problems that need to be anticipated in mangrove management. First is potential over expansion of aquaculture fish ponds due to economic pressure (Wahyuni et al. 2014). The result of interviews with communities and relevant stakeholders (local government, extensionis, NGO) found that total area of fish ponds tend to increase. This coincides with meta analysis study on mangrove value in Souteast Asia done by Brander et al. (2012) who argued.that degradation and conversion of mangroves in Southeast Asia is mainly due to the expansion of shrimp aquaculture cultivation. Without disregarding struggle of people to maintain and expand mangrove forest in East Sinjai, for some people, expansion of mangrove is a motive to expand fish ponds. In other words, after people succeeded in growing and expanding mangrove plants, they plan to open mangrove on the inside part to be converted into fish pond. They have no guilty feeling as total area of mangrove is not reduced (new pond area is equal to the area of mangrove planted earlier). This should be a concern of all parties, because if economy burden continued to increase (population growth, inflation) while alternative sources of income are limited, it is possible that conversion of mangroves into fishponds would be done extensively in the future even before they set up area for replacing mangrove as mangrove is slow-growing species.

Another issue associated with the expansion of aquaculture fishpond is land suitability. Most suitable soil type for aquaculture fishpond should contain a lot of clay and little sand (Baderan 2013). Soil type in Panaikkang and Passimarannu village are predominantly sandy, so less able to hold water due to its high level of soil porosity. In addition, its soil structure is fragile and more quickly decompose causing less suitable for fishpond cultivation as pond dike is prone to landslides and easily destroyed.

From the above discussion, it is expected that the study on the total economic value of mangrove ecosystems in East Sinjai along with some issues that should be anticipated can be used as a reference to formulate strategies for optimal mangrove ecosystem management in East Sinjai. Eventually, existing ecosystem is expected to be sustainably maintained while still providing the maximum economic benefit to surrounding community.

\section{Conclusion}

The benefits of mangrove ecosystems identified in East Sinjai consist of direct benefits (polyculture fishpond cultivation, catching aquatic biota including crabs, shrimp, fry, fingerling and hatchling, fuelwood collection and bats catching); indirect benefit (to prevent abrasion and seawater intrusion; option benefit of biodiversity values; and existence benefit value bestowed by local people. Total potential economic value of mangrove in East Sinjai is IDR 37,535,809,496 year ${ }^{-1}$. Indirect values contribute the highest portion to total income $(52.43 \%)$, followed by direct values $(46.26 \%)$, existence value $(0.90 \%)$ and option value $(0.41 \%)$ respectively. To optimize mangrove management, there are potential benefits that have not been developed i.e benefit as tourist area and its function as natural laboratory (for education and research). This potential benefits need to be developed to increase alternative sources of community's income while encouraging them to participate in mangrove conservation. The problems that need to be anticipated is over expansion of polyculture fishpond as it contributes quick and direct significant income.

\section{Recommendation}

In formulating strategies for optimal mangrove ecosystem management, research results on total economic value of mangrove ecosystems along with some issues that need to be anticipated including identification and development of unexplored mangrove benefits (ecotourism; natural laboratory) and the need to establish professional management by involving relevant stakeholders such as local government, private sector, and local communities 
should be taken into account as the basic consideration hence any management option selected would not generate negative externality for its surrounding community.

\section{Acknowledgement}

The authors would like to express sincerely gratitude to Indonesia's Ministry of Environment and Forestry for providing funding for the study under "research school program".

\section{References}

Alongi DM. 2012. Carbon sequestration in mangrove forests. Carbon Management 3(3):313-322.

Asbar 2007. Optimalisasi pemanfaatan kawasan pesisir untuk pengembangan budidaya tambak berkelanjutan di Kabupaten Sinjai, Sulawesi Selatan [dissertation]. Bogor: Bogor Agricultural University.

Atheull AN, Din N, Koum LGE, Satyanarayana B, Koedam N, Guebas FD. 2011. Assessing forest products usage and local residents'perception of environmental changes in per-urban and rural mangrves of Cameroon, Central Africa. Journal of Ethnobiology and Ethnomedicine $7(1): 41$

Baderan DWK. 2013. Model valuasi ekonomi sebagai dasar untuk rehabilitasi kerusakan hutan mangrove di wilayah pesisir Kecamatan Kwandang, Kabupaten Gorontalo Utara, Provinsi Gorontalo [dissertation]. Yogyakarta: Universitas Gadjah Mada.

Borokini TI, Ighere DA, Ajiboye TO, Alowonhe AA. 2013. Ethnobiological survey of traditional medicine practices in Oyo State. Journal of Medicinal Plant Studies 1(5):1-16

Brander LM, Wagtendonk AJ, Hussain SS, McVittie A, Verburg PH, de Groot RS, van der Ploeg S. 2012. Ecosystem service values for mangroves in Southeast Asia: A meta-analysis and value transfer application. Ecosystem Services 1:62-69.

Cai WJ. 2011. Estuarine and coastal ocean carbon paradox: $\mathrm{CO}_{2}$ sinks or sites of terrestrial carbon incineration? Annual Review of Marine Science 3:123-145. http://dx.doi.org/10.1146/annurev-marine-120709142723

Carandang AP, Camacho LD, Gevaña DT, Dizon JT, Camacho SC, de Luna CC, Pulhin FB, Combalicer EA, Paras FD, Peras RJJ, Rebugio LL. 2013. Economic valuation for sustainable mangrove ecosystems management in Bohol and Palawan, Philippines. Forest Science and Technology 9(3):118-125.

Chumura GL, Anisfeld SC, Cahoon DR, Lynch JL. 2003. Global carbon sequestration in tidal, saline wetland soils. Global Biochemical Cycles 17(4):111. http://dx.doi.org/ 10.1029/2002GB001917.
Darusman D. 2012. Kehutanan demi Keberlanjutan Indonesia. Bogor: IPB Press.

Dinas Kelautan dan Perikanan Kabupaten Sinjai 2014. Laporan Akhir Inventarisasi dan Pemetaan Luasan Lahan Budidaya Tambak di Kabupetan Sinjai. Sinjai: Dinas Kelautan dan Perikanan.

Dinas Perkebunan dan Kehutanan Kabupaten Sinjai. 2013. Statistik Perkebunan dan Kehutanan Sinjai. Sinjai: Dinas Perkebunan dan Kehutanan Kabupaten Sinjai.

Din N, Saenger P, Jules PR, Siegried DD, Basco F 2008, 'Logging activities in mangrove forests: A case study of Douala Cameroon', African Journal of Environmental Science and Technology 2(2):22-30. http://www.aca demicjournals.org/AJest

Fauzi A. 2004. Ekonomi Sumber Daya Alam dan Lingkungan. Jakarta: Gramedia Pustaka Utama.

Giri C, Zhu Z, Tiesen LL, Singh A, Gillete S, Kelmelis JA. 2008. Mangrove forest distributions and dynamics (1975-2005) of the tsunami-affected region of Asia. Journal of Biogeography 35:519-528. http://dx.doi.org/ 10.1111/j.1365-2699.2007.01806.x

Harahap N. 2010. Penilaian Ekonomi Ekosistem Hutan Mangrove dan Aplikasinya dalam Perencanaan Wilayah Pesisir. Yogyakarta: Graha Ilmu.

Hiariey LS. 2009. Identifikasi nilai ekonomi ekosistem hutan mangrove di Desa Tawiri, Ambon. Jurnal Organisasi dan Manajemen 5(1):23-34.

Indrayanti MD, Fahrudin A, Setiobudiandi I. 2015. Penilaian jasa ekosistem mangrove di Teluk Blanakan, Kabupaten Subang. Jurnal Ilmu Pertanian Indonesia 20(2):91-96. http://dx.doi.org/10.18343/jipi.20.2.91.

Kalitouw DW. 2015. Potensi ekonomi ekosistem hutan mangrove di Desa Kulu, Kecamatan Wori, Kabupaten Minahasa Utara [thesis]. Bogor: Bogor Agricultural University.

Karminarsih E. 2007. The use of ecosystemmangrove in minimalize disaster impact in beach area. Jurnal Manajemen Hutan Tropika 18(3):182-187.

Kildow JT, Guo J. 2014. The gap between science and policy: Assessing the use of nonmarket valuation in Estuarine management. Working Paper 2. http://citeseerx.ist.psu. edu/viewdoc/download?doi=10.1.1.671.5328\&rep=rep 1\&type=pdf. [2 August 2015].

Kusmana C. 2010. General information for Indonesian mangrove. Paper presented of the workshop of FHRD Committee and Mangrove Rehabilitation/Restoration, 5 August 2008, Rimbawan II Room, Manggala Wanabakti, Ministry of Forestry, Jakarta. http://cecep_kusmana. staff.ipb.ac.id/2010/06/15/general-information-forindonesian-mangrove/. [4 July 2014] 
Kustanti A. 2011. Manajemen Hutan Mangrove. Bogor: IPB Press.

Malik A, Fensholt R, Mertz O. 2015. Economic valuation of mangroves for comparison with commercial aquaculture in South Sulawesi, Indonesia. Forests 6:3028-3044.

Manan S. 1985. Pengaruh Hutan dan Manajemen Daerah Aliran Sungai. Bogor: Departemen Manajemen Hutan, Fakultas Kehutanan IPB.

Mayudin A. 2012. Kondisi ekonomi pasca konversi hutan mangrove menjadi lahan tambak di Kabupaten Pangkajene Kepulauan, Povinsi Sulawesi Selatan. Junal EKSOS 8 (2):90-104

Miswadi, Siregar SH, Siregar YI. 2015. Strategi pengelolaan kawasan penyangga sebagai hutan cadangan mangrove (Studi kasus ekosistem mangrove Sungai Liung Kecamatan Bantan Kabupaten Bengkalis). Dinamika Lingkungan Indonesia 2(2):73-86.

Munasinghe M. 1993. Environmental Economics and Sustainable Development. Washington DC: The World Bank.

Napitupulu L, Trinidad AC, Titaningtyas. 2012. The worth of coastal ecosystems in the Coral Triangle. In: Proceedings of the 12 th International Coral Reef Symposium; Cairns, Australia, July 9-13, 2012.

Ojha HR. 2009. Reducing emission from deforestation and forest degradation (REDD) program. Journal of Forest and Livelihood 8(1):67-77.

Ostrom E. 1990. Governing The Commons. The Evolution of Institutions for Collective Action. Cambridge: University Press.

Patil V, Singh A,Naik N, Seema U, Sawant B. 2012. Carbon sequestration in mangroves ecosystems. Journal of Environmental Research and Development 7(1A):576-583.

Pearce D, Moran D. 1994. The Economic Value of Biodiversity. London: IUCN-The World Conservation Union.,

Picaulima SM, Huliselan NV, Sahetapy D, Abrahamsz J. 2011. Pengelolaan ekosistem mangrove berbasis ekonomi sumber daya dan lingkungan di Negeri Rutong, Kota Ambon. 2011. Jurnal Ichthyos 10(1):49-56.

Rachmansyah Y, Maryono J. 2010. Pentingnya valuasi ekonomi dalam pengelolaan kawasan konservasi yang lestari. Prestasi 6(2):100-110

Ramdani F, Rahman S, Setiani P. 2015. Inexpensive method to asses mangroves forest through the use of open source software and data available freely in public domain
Journal of Geographic Information System 7:43-57. http://dx.doi.org/10.4236/jgis.2015.71004.

Ruitenbeek HJ. 1992. Mangrove management: An economic analysis of management options with a focus on Bintuni Bay, Irian Jaya. In: Environmental management development in Indonesia Project (EMDI). Canada: Dalhousie University Printing Centre.

Rusdianah 2006. Kajian ekonomi dan ekologi pemanfaatan ekosistem mangrove di Pesisir Tongke-tongke Kabupaten Sinjai, Sulawesi Selatan [thesis], Bogor: Bogor Agricultural University.

Samsudin I. 2015. Model pengelolaan ekosistem mangrove berbasis ekominawisata di Desa Tongke-tongke, Kecamatan Sinjai Timur, Sinjai [thesis]. Makassar: Univesitas Muslim Makassar.

Sawitri R, Bismark M, Karlina E. 2013. Ekosistem mangrove sebagai obyek wisata alam di kawasan konservasi mangrove dan bekantan di Kota Tarakan. Jurnal Penelitian dan Konservasi Alam 10(3):297-314.

Sena AMC. 2009. A theoretical essay on sustainability and environmentally balanced output growth: natural capital, constrained depletion of resources and pollution generation. BAR-Brazilian Administration Review 6(3):213-229. http://dx.doi.org/10.1590/S180776922009000300004

Siregar AF. 2012. Valuasi ekonomi dan analisis strategi konservasi hutan mangrove di Kabupaten Kubu Raya, Provinsi Kalimantan Barat [thesis]. Bogor: Bogor Agricultural University.

Soedomo S. 2013. Total economic value in investment analysis. Jurnal Manajemen Hutan Tropika 19 (2):201-207. DOI: $10.7226 / \mathrm{jtfm} .19 .3 .201$.

Spaninks F, Beukering PV. 1997. Economic valuation of mangrove ecosystems: Potential and Limitations. CREED Working Paper No.14. The Netherlands: Institute for Environmental Studies (IVM).

Uphoff N. 2000. "Understanding Social Capital: Learning from The Analysis and Experience of Participation". Social Capital: A Multifaceted Perspective. Dasgupta P, Serageldin I, editors. Washington DC: The World Bank.

Wahyuni Y, Putri EIK, Simanjuntak SMH. 2014. Valuasi total ekonomi hutan mangrove di kawasan Delta Mahakam Kabupaten Kutai Kartanegara, Kalimantan Timur. Jurnal Penelitian Kehutanan Wallacea 3(1):1-12.

Yap, WG, Villaluz AC, Soriano MGG, Santos MN. 2007. Milkfish production and processing technologies in the Philippines. Milkfish Project Publication Series No. 2.96 pp. 